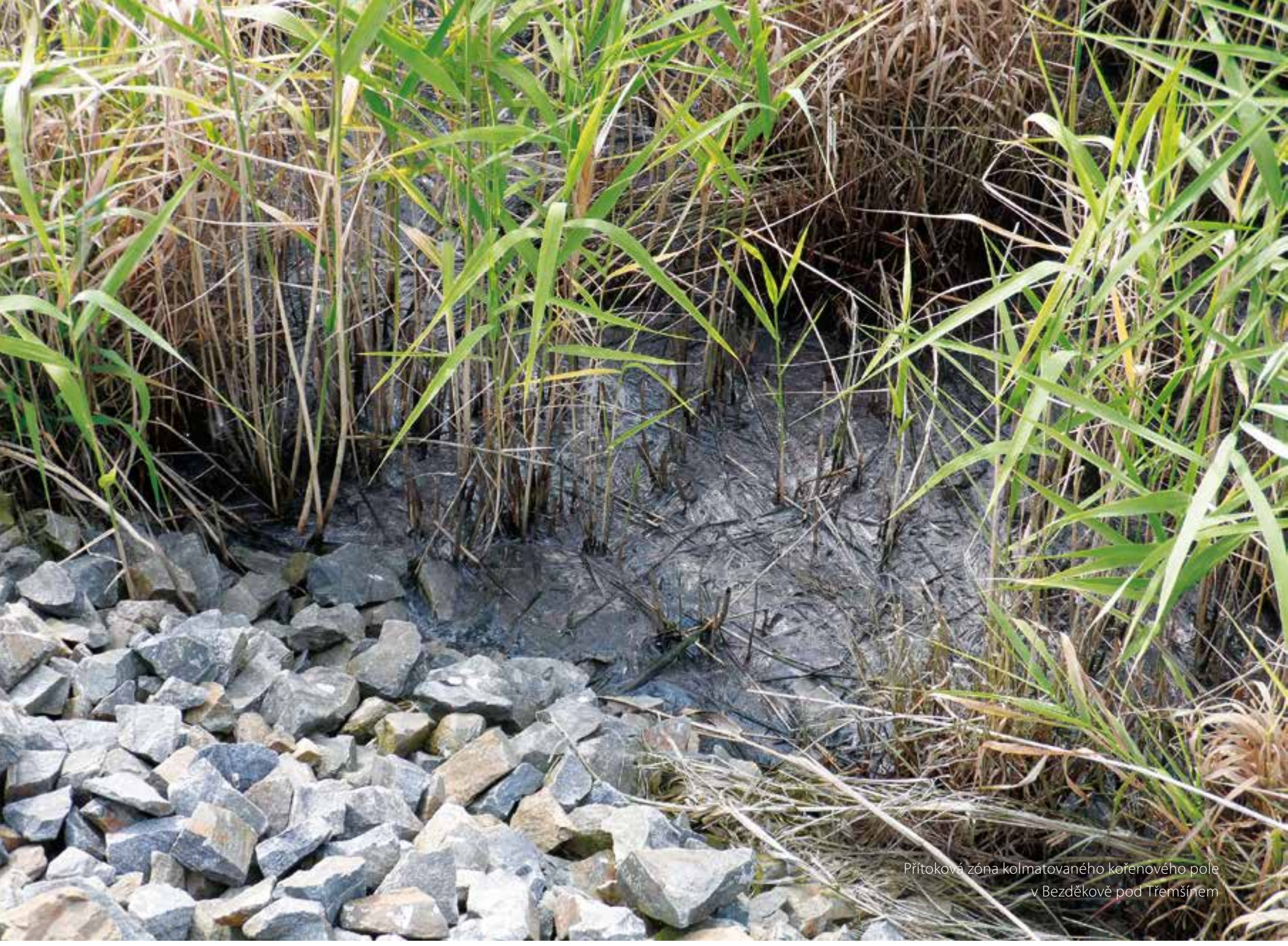

\title{
Kolmatace umělých mokřadů
}

\section{EVA MLEJNSKÁ}

Klíčová slova: kolmatace - umělé mokřady - účinnost čištění - zatížení

\section{SOUHRN}

Kolmatace je zcela přirozeným jevem, ale v umělých mokřadech využivaných k čištění a dočištování odpadních vod je jevem nežádoucím. Proto je nutné při návrhu a provozování umělých mokřadů dodržovat zásady, které mohou vznik a rozvoj kolmatace významně omezit. Patří mezi ně zejména dostatečné dimenzování a správné provozování mechanického předčištění, vhodná volba zrnitosti filtrační náplně umělého mokřadu, látkové a hydraulické zatěžování, provozní podmínky. Pokud ke kolmataci dojde a její rozsah ovlivňuje účinnost čištění nebo množství vyčištěné odpadní vody, je třeba přistoupit k výměně nebo regeneraci filtrační náplně umělého mokřadu. Článek shrnuje zkušenosti s in-situ aplikací bakteriálně-enzymatického preparátu do zakolmatovaného kořenového pole. 


\section{ÚVOD}

V kořenových čistírnách (horizontálně nebo vertikálně podpovrchově protékaných umělých mokřadech), které jsou v malých obcích poměrně běžně využívanou technologií čištění odpadních vod, probíhá celá řada procesů spojených nejen s vlastním čištěním, ale také s kolmatací. Kolmatace je na rozdíl od čisticích procesů jevem nežádoucím. Jde o souhrn fyzikálních, chemických a biologických procesů, které vedou ke snižování porozity a propustnosti (hydraulické vodivosti) náplně umělého mokřadu [1-6], dále významně ovlivňuji přenos kyslíku ze vzduchu do vody [7-9]. Tyto skutečnosti mají za následek snižování účinnosti čištění, tedy významný pokles schopnosti systému čistit odpadní vodu.

Dochází ke snížení množství dostupné filtrační náplně, zvýšení rychlosti proudění a snížení doby zdržení čištěné odpadní vody v systému a velice často také k povrchovému a zkratovému proudění [10].

U umělých mokřadů mluvíme zejména o kolmataci náplně nerozpuštěnými látkami, především jemnými minerálními a organickými částicemi z povrchových smyvů, kalem vyplavovaným ze stokové sítě a mechanického stupně čištění. Dalšími příčinami mohou být nevhodně rešené deštové oddělovače, nevhodně zvolený (většinou př́liš jemný) materiál filtrační vrstvy nebo pronikání sekundárního znečištění z předřazené biologické nádrže, zejména v letním období [11]. Rozsah kolmatace závisí na množství látek (vyjádřeno ukazateli $\mathrm{CHSK}_{\mathrm{C}^{\prime}}$ nerozpuštěné látky) v pritékající odpadní vodě [2], hydraulickém zatížení umělého mokřadu [3], zrnitostním složením náplně, jeho struktuře a textuře, době provozu zařízení atd.

Ke kolmataci filtračního prostředí může dojít bud' nárazovým uvolněním těchto částic, např. při přivalových deštích nebo významnějších srážkových událostech, dále potom hydraulickým přetěžováním umělých mokřadů [12] nebo pozvolným zakolmatováním, které způsobuje především nevhodná konstrukce usazovacích nádrží nebo jejich nesprávné provozování a údržba, např. nedostatečné průběžné vyvážení usazeného kalu [13]. Příčinou může být i nevhodně zvolený materiál filtrační náplně umělého mokřadu nebo jeho nevhodná zrnitost.

Kolmatace může vznikat i tzv. interními zdroji, kterými jsou odpad z růstu biomasy, kořenů rostlin, dále potom detrit z biofilmu a rostlin, pevné látky zanešené během výstavby umělého mokřadu nebo pevné látky z chemické eroze štěrku [14].

\section{VLIV MECHANICKÉHO PŘEDČIŠTĚNÍ}

Kolmataci je možné omezit především volbou vhodného a dostatečně dimenzovaného mechanického predčištění, zejména pak usazovací nádrže. Kalový prostor usazovacích nádrží a lapáků písku je nezbytně nutné dostatečně často vyvážet. Zhoršení usazovací schopnosti je možné monitorovat zvyšujícími se koncentracemi nerozpuštěných látek na odtoku ze stupně mechanického predčištění.

\section{VLIV ZATÍŽENÍ}

Literární data týkající se látkového zatížení jsou vzácně ve shodě. Autoři Platzer a Mauch [15] uvádějí jako prevenci vzniku kolmatace v klimatických podmínkách střední Evropy maximální zatížení (vyjádřeno ukazatelem $\left.\mathrm{CHSK}_{\mathrm{c}}\right) 25 \mathrm{~g} /\left(\mathrm{m}^{2}\right.$.den). Systémy mohou být zatěžovány i více, pokud jsou provozovány s využitím cyklů (přerušovaný provoz). Autoři Winter a Goetz [2] uvádějí, že zatížení CHSK ${ }_{C r}$ a nerozpuštěnými látkami by $v$ klimatických podmínkách střední Evropy nemělo překročit $20 \mathrm{~g} /\left(\mathrm{m}^{2}\right.$.den), resp. $5 \mathrm{~g} /\left(\mathrm{m}^{2}\right.$.den). Autoři Hua a kol. [16] uvádějí, že pro vertikálně protékané umělé mokřady by koncentrace nerozpuštěných látek neměla překročit hodnotu 100 mg/l a maximální zatížení hodnotu
$5 \mathrm{~g} /\left(\mathrm{m}^{2}\right.$.den), resp. $20 \mathrm{~g} /\left(\mathrm{m}^{2}\right.$.den), vyjádřeno ukazatelem $\mathrm{CHSK}_{\mathrm{cr}}$. Autorky Tuszyńska a Obarska-Pempkowiak [17] uvádějí, že maximální látkové zatížení (vyjádřeno ukazatelem $\mathrm{CHSK}_{\mathrm{Cr}}$ ), které ještě nezpůsobí kolmataci v klimatických podmínkách střední Evropy, je $25 \mathrm{~g} /\left(\mathrm{m}^{2}\right.$.den).

Tendence ke kolmataci koreluje s celkovou koncentrací nerozpuštěných látek v pritékající odpadní vodě. Nezakolmatované umělé mokřady jsou charakterizovány nízkým látkovým zatížením a nízkými vstupními koncentracemi nerozpuštěných látek, částečně kolmatované nízkým látkovým zatížením a vyššími vstupními koncentracemi nerozpuštěných látek, kolmatované potom vysokým látkovým zatížením a vysokými vstupními koncentracemi nerozpuštěných látek. Z toho plyne, že je nutné umělé mokřady co nejlépe chránit před nerozpuštěnými látkami.

\section{VLIV VEGETACE}

Podle našich zkušeností je ukládání stařiny mokřadní vegetace závažným problémem. Po několika letech provozu může mocnost takto vytvořené vrstvy dosáhnout až $20 \mathrm{~cm}$. Uložený materiál se postupně rozkládá a přispívá ke kolmataci filtrační náplně. Proto je důležité důkladně z povrchu osázeného umělého mokřadu odstraňovat stařinu mokřadní vegetace [18]. Žádoucí je pravidelné časně jarní odstraňování zbytků vegetačního pokryvu [19].

\section{VLIV FILTRAČNÍ NÁPLNĚ}

Filtrační náplň je jednou ze tří základních součástí umělého mokřadu a její výběr je pro jeho správnou funkci zásadní. Vlastnosti filtračních materiálů, zejména hydraulická vodivost, se během provozu mění. Propustnost filtrační náplně je ovlivňována zhutněním (údržba, přirozené sesedání), prorůstáním kořeny a ukládáním stařiny mokřadní vegetace, kolmatací volných pórů nerozpuštěnými látkami apod. [20]. Nevhodně zvolená frakce kameniva v nátokové zóně může mít spolu s dalšími faktory za následek vznik a rozvoj kolmatace. Vzhledem k tomu, že i vlastní filtrační náplň mủže přispívat k rozvoji kolmatace, doporučuje se používat zrnité materiály, které jsou čisté, s nízkým obsahem vápence nebo rozložitelných minerálních látek. K hlavním opatřením, která významně omezují rozsah a prủběh kolmatace, patří navrhování postupného přechodu zrnitostního složení filtrační náplně [19].

\section{VLIV PROVOZNÍCH PODMÍNEK}

Vedle volby vhodné filtrační náplně a hydraulického a látkového zatížení může průběh kolmatace významně ovlivnit i dávkovací strategie a také rovnoměrné rozdělení mechanicky preděištěné odpadní vody po celé šiři filtračního pole [19]. Autoři Zhao a kol. [21] zjistili sledováním sta umělých mokřadů, že rychlost infiltrace Ize vrátit na téměř původní úroveň, pokud jsou príijata vhodná provozní nastavení, tzn. plnění a klidové periody kořenových polí. Akumulované organické látky jsou pak efektivněji rozkládány mikroorganismy.

\section{VLIV TEPLOTY}

Dalším z parametrů ovlivňujících kolmataci je teplota. Vyšší teploty souvisí s vyšší biologickou aktivitou a vyššími růstovými rychlostmi, to vede k rychlejšímu odbourávání organických látek akumulovaných v pórech, ale na druhou stranu jsou póry zaplňovány vyšším přirůstkem biomasy. 


\section{DŮSLEDKY KOLMATACE}

Kolmatace je doprovázena nejen zhoršením účinnosti čištění, ale také hydraulickými poruchami, jako je zaplavování povrchu filtračních polí odpadní vodou, tzn. preferenčním tokem odpadní vody po povrchu umělého mokřadu, nebo vznikem zkratového proudění nevyčištěné odpadní vody filtrační náplní [5, 14]. Zaplavování povrchu má za následek zvyšování zápachu v okolí umělého mokřadu, dále možnost kontaktu osob s odpadní vodou a v neposlední řadě také možnost zvýšeného výskytu komárů [13]. Zkratové proudění nepř́iznivě ovlivňuje účinnost čištění, protože významně snižuje dobu zdržení odpadní vody v systému. Pokud je kolmatace filtrační náplně umělého mokřadu rozsáhlá, ovlivňuje účinnost čištění, případně množství vyčištěné odpadní vody, je třeba hledat metody, jak kolmataci odstranit nebo alespoň omezit.

\section{METODY ODSTRANĚNÍ KOLMATACE}

Pokud dostatečně nefungují přijatá preventivní opatření, která zahrnují využití dostatečně dimenzované usazovací nádrže, správné provozování mechanického předčištění, nastavení co nejvhodnějších zatěžovacích parametrů a vhodných změn v hydraulickém zatí̌ení (přerušovaný provoz, promývání, obrácený směr toku odpadní vody apod.), a dojde $k$ částečné nebo úplné kolmataci filtrační náplně umělého mokřadu, je třeba přikročit $k$ nápravným opatřením [16, 22]. V současné době je známo několik metod revitalizace ucpaných filtračních náplní, některé z nich ale prozatím nebyly testovány v reálném měřítku a jsou spíše teoretickými možnostmi.

$\checkmark$ minulosti se nejčastěji používala výměna části nebo celé filtrační náplně. Výměna filtrační náplně spočívá v odstranění kolmatované části nebo celé filtrační náplně a její nahrazení novým praným kamenivem nebo jinou vhodnou náplní stejných nebo upravených frakcí. V prrípadě výměny části filtrační náplně je třeba před realizací vyhodnotit rozsah kolmatace a určit část filtrační náplně nutné k výměně.

Další možností je regenerace stávající filtrační náplně. V podstatě existují tři možné způsoby regenerace filtračních náplní umělých mokřadů:

- odstraňování usazeného kalu ze zakolmatované filtrační náplně proplachováním, bakteriálním rozkladem, chemickým rozkladem apod. - tyto procesy se provádějí prímo v umělém mokřadu, odstávka regenerované části umělého mokřadu není dlouhodobá;

— vytěžení zakolmatované filtrační náplně, její ponechání v tenké vrstvě přes zimní období na zpevněné ploše odvodněné přes lapák písku a vyplavení kalových částic deštěm a následně vodou - provádí se mimo umělý mokřad, je třeba mít k dispozici zpevněnou plochu, odstávka je dlouhodobější;

- vytěžení zakolmatované filtrační náplně a její následná regenerace ve speciálních pračkách - provádí se mimo umělý mokřad, pračky kameniva u nás zatím nejsou běžně používanou technologií, navíc zde nastává problém, jak naložit se znečištěnou prací vodou.

Všechny tyto možnosti regenerace filtrační náplně vyžadují uzpůsobené uspořádání umělého mokřadu umožňující čistit v období regenerace odpadní vodu v jiné části umělého mokřadu, tedy např. paralelní zapojení kořenových polí nebo bypass v sériovém zapojení kořenových polí.

Všechny tyto metody jsou vysoce účinné, ale zejména varianty (2) a (3) jsou spojeny se značnými finančními náklady. Autor Kršňák [23] uvádí, že varianta vyprání štěrkové náplně je oproti úplné výměně nebo metodě vymrznutí finančně nejdostupnější. Ale je třeba brát v úvahu fakt, že dochází k vyřazení umělého mokřadu z provozu mnohdy i na několik měsíců.

Vzhledem ke skutečnosti, že je výměna nebo regenerace filtrační náplně značně nákladná, je nutné hledat jednodušší a levnější metody odstranění kolmatace. Autoři Li a kol. [9] poukazují na možnost využití žižal (Eisenia foetida,

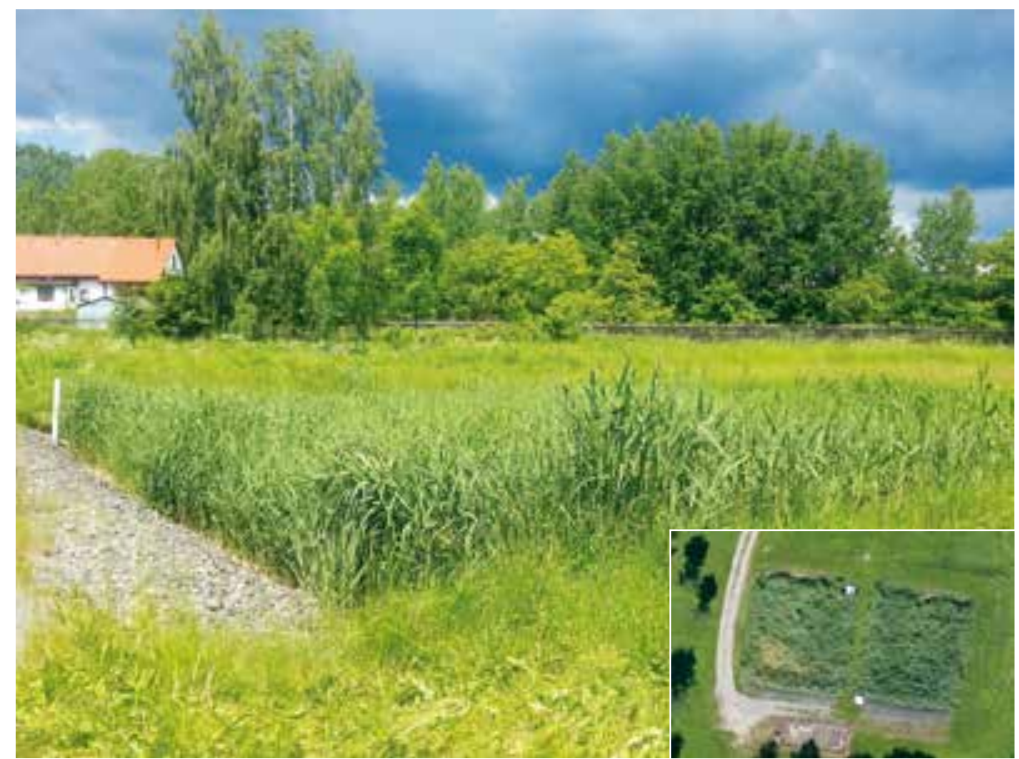

Obr. 1. Pohled na levé kořenové pole čistírny Bezděkov pod Třemšínem a letecký pohled na celou kořenovou čistírnu

Fig. 1. View on the left part of the constructed wetland of Bezděkov pod Třemšínem wastewater treatment plant and air view on the whole constructed wetland

Pheretima guillelmi). Ty mohou pomoci nejen uvolnit substrát, ale také odstranit nahromaděné organické látky. Výzkum ukázal, že použití druhu Eisenia foetida je vhodnější, protože množství nahromaděných nerozpuštěných organických látek kleslo o $90 \%$, z toho bylo 40 \% preměněno na rozpuštěné organické látky a 50 \% na rozpuštěné anorganické látky. Tato metoda je však spíše alternativní než prakticky využitelná v masovém měřítku.

Jako další alternativní metoda regenerace filtračního lože se v poslední době zkouší in-situ aplikace různých druhů přípravků, které by účinně odstranily nakumulované nerozpuštěné látky a uvolnily filtrační lože bez nutnosti jeho mechanického čištění. Autoři Nivala a Rousseau [24] popisují dvě prípadové studie regenerace filtračního lože kořenových čistíren za použití 35\% roztoku peroxidu vodíku, který je schopen oxidovat jinak biologicky neodbouratelné části biofilmu, které mohou tvořit více než 60 až $75 \%$ váhy biomasy ve filtrační náplni. Výsledky výzkumu ukazují, že se regenerace filtrační náplně peroxidem vodíku zdá být nadějnou cestou k odstranění kolmatace v podpovrchově protékaných umělých mokřadech.

Autoři Hua a kol. [16] se experimentálně zabývali možnostmi odstranění usazených nerozpuštěných látek z filtračního lože kořenové čistírny za pomoci dávkování čtyř různých roztoků, a to konkrétně roztoku hydroxidu sodného $(\mathrm{NaOH})$, chlornanu sodného ( $\mathrm{NaClO}$ ), kyseliny chlorovodíkové $(\mathrm{HCl})$ a speciálně pripraveného detergentu. Efektivní porozita i infiltrační rychlost se nejrychleji a nejvíce zlepšovala při použití roztoku chlornanu sodného. Při použití vodovodní vody (srovnávací roztok) se efektivní porozita téměř neměnila a rychlost infiltrace jen velmi nepatrně stoupala. Proteiny a polysacharidy byly rozpuštěny hlavně roztokem hydroxidu a chlornanu sodného a anaerobně vytvořený plyn uložený v pórech byl uvolněn roztokem kyseliny chlorovodíkové.

Obě tyto studie sice prokázaly dobrou účinnost in-situ regenerace zakolmatovaného filtračního lože aplikací výše uvedených přípravků, na druhé straně došlo jejich vlivem k dočasnému poškození biofilmu a také kořenů mokřadní vegetace. Autoři uvádějí, že po aplikaci těchto prípravků následovalo období cca 1 měsíce regenerace biofilmu filtračního lože.

Výzkumný ústav vodohospodářský T. G. Masaryka, veřejná výzkumná instituce, v posledních letech testuje možnosti využití in-situ aplikace směsí bakteriálně enzymatických prípravků do kolmatovaných zemních filtrů [25] a kořenových čistíren. 


\section{TESTOVACI LOKALITA}

K testování in-situ aplikace bakteriálně enzymatického preparátu byla vybrána kořenová čistírna Bezděkov pod Třemšínem (obr. 1). Jedná se o obecní kořenovou čistírnu odpadních vod s kapacitou 150 EO, která se skládá z česlí, lapáku písku, štěrbinové usazovací nádrže objemu $39 \mathrm{~m}^{3}$ a dvou paralelně zapojených, horizontálně podpovrchově protékaných kořenových polí s celkovou plochou cca 790 m². Porost kořenových polí tvoří rákos obecný, který je sečen jednou ročně. Kanalizace přivádějící odpadní vodu je oddílná. Do trvalého provozu byla tato kořenová čistírna uvedena v listopadu roku 2004. Jako náplň je použito jemné drcené kamenivo.

Vlastní aplikace preparátu probíhala ve dvou fázích, a to od 22. 5. 2013 do 10. 7. 2013 (8 týdnů) a od 3. 6. 2014 do 22. 7.2014 (8 týdnů). Po dobu odstávky pravého kořenového pole byla veškerá odpadní voda čištěna na paralelním (levém) kořenovém poli, kvalita odtékající vyčištěné odpadní vody byla pravidelně kontrolována. Stejně tak před započetím vlastního experimentu a po jeho ukončení probíhalo pravidelné sledování vybraných parametrů na př́toku, za mechanickým předčištěním a na odtoku z jednotlivých kořenových polí. Kořenové pole, do kterého probíhalo dávkování preparátu, zůstalo po dobu experimentu zatopeno, pouze byl zastaven průtok odpadní vody.

$\checkmark$ roce 2013 probíhal experiment následovně: $v$ den zahájení experimentu bylo vybrané kořenové pole odstaveno z provozu, preparát byl dávkován $\checkmark$ předem určených termínech do několika míst prítokové zóny (ve vzdálenosti cca 1,5 metru od začátku kořenového pole). Preparát byl před vlastní aplikací aktivován rozpuštěním v odpadní vodě odebrané za mechanickým předčištěním. Aplikován byl na povrch kořenového pole. Celkem proběhlo 6 aplikací preparátu (2 kg 22. 5. 2013, 1 kg 29. 5. 2013, nic 5. 6. 2013, 1 kg 12. 6. 2013, nic 19. 6. 2013, 1 kg 26. 6. $2013,1 \mathrm{~kg}$ 3. 7. $2013,1 \mathrm{~kg}$ 10. 7. 2013). Devátý týden experimentu bylo odstavené kořenové pole uvedeno do provozu.

$\checkmark$ roce 2014 probíhal experiment následovně: pred vlastním odstavením pravého kořenového pole z provozu a aplikací preparátu proběhlo očištění části povrchu prítokové zóny od stařiny (obr. 2) a nashromážděného organického materiálu, aby mohlo dojít k porovnání mezi částí kořenového pole bez stařiny a se stařinou. Čištění probíhalo, s ohledem na množství stařiny a náročnost jejího odstranění, ve dvou fázích a s týdenním krokem, po dalších 14 dnech byla

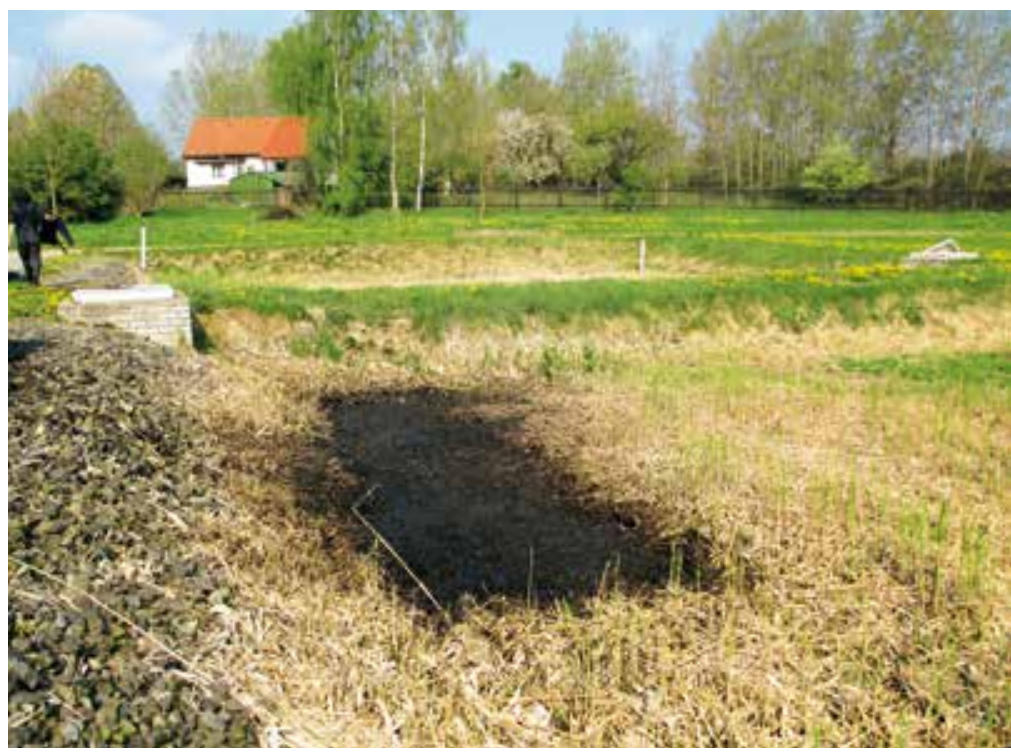

Obr. 2. Pohled na př́tokovou zónu pravého kořenového pole očištěnou od stařiny a usazeného kalu

Fig. 2. View on the inflow zone of the right part of the constructed wetland cleared from the old vegetation and settled sludge

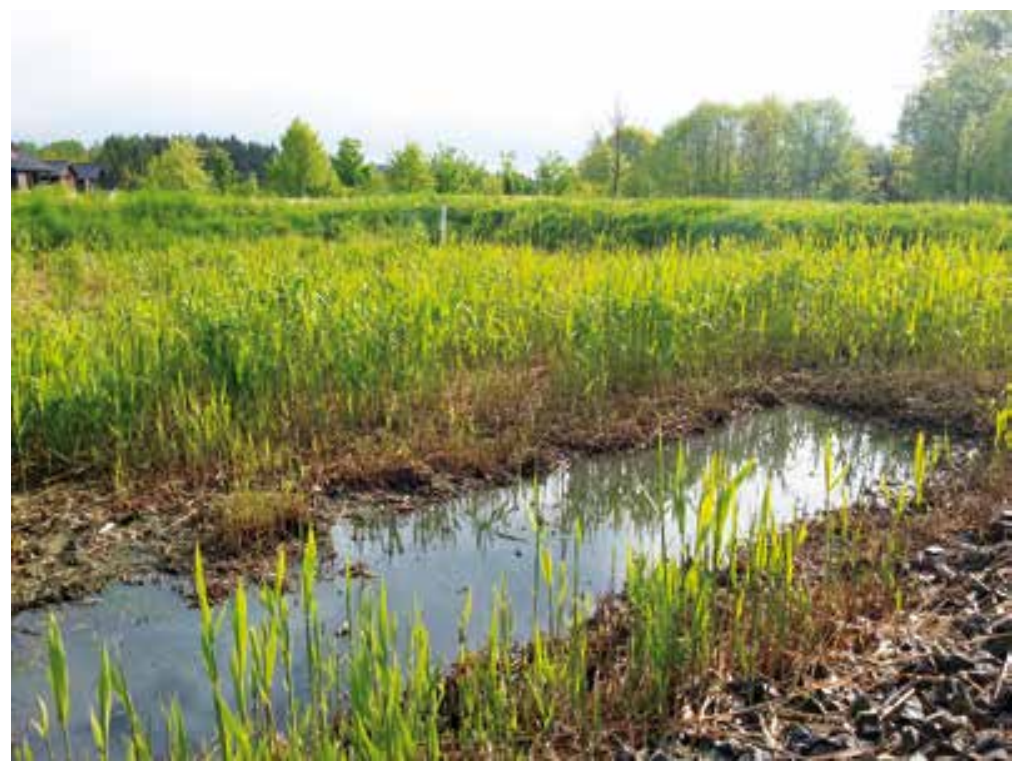

Obr. 3. Pohled na očištěnou část pravého kořenového pole po 14 dnech

Fig. 3. View on the cleared sector of the right part of the constructed wetland

odklizená část nalezena zatopená čištěnou odpadní vodou (obr. 3). Zatopení odklizené části bylo způsobeno nevhodným nastavením výšky hladiny v kořenovém poli, která je regulována prostřednictvím odtokové roury. V den zahájení experimentu (3. 6. 2014) bylo vybrané kořenové pole odstaveno z provozu, preparát byl dávkován $v$ predem určených termínech do několika míst př́tokové zóny (ve vzdálenosti cca 1,5 m od začátku kořenového pole). Preparát byl před vlastní aplikací aktivován rozpuštěním v odpadní vodě odebrané za mechanickým předčištěním. Aplikován byl na povrch kořenového pole. Celkem proběhlo 8 aplikací preparátu (2 kg 3. 6. 2014, 1 kg 10. 6. 2014, 1 kg 17. 6. 2014, 1 kg 24. 6. 2014, 0,5 kg 1.7. 2014, 0,5 kg 8. 7.2014, 0,5 kg 15.7.2014, 5 kg 22. 7. 2014), po znovuuvedení kořenového pole do provozu byl preparát dále dávkován do rozdělovací šachtice za mechanické předčištění (0,5 kg 29. 7. 2014 a 0,5 kg 5. 8. 2014).

V tomto článku není podrobněji diskutováno složení preparátu, které je obchodním tajemstvím výrobce. Lze pouze konstatovat, že se jedná o speciálně komerčně připravenou směs bakterií a enzymů.

S ohledem na nemožnost přesného měření průtoku na odtoku z jednotlivých kořenových polí bylo měření prováděno pouze orientačně. Průtok pravým a levým kořenovým polem byl zpravidla velice podobný a pohyboval se většinou $v$ rozmezí od 0,5 do $11 / \mathrm{s}$.

\section{VÝSLEDKY TESTOVÁNÍ}

Cílem experimentu bylo ověřit, jestli může dávkování preparátu účinně snižit míru kolmatace umělého mokřadu, a tím zvýšit jeho prưchodnost a účinnost čištění, a dále ověřit, jestli nedojde ke snížení účinnosti čištění kořenového pole, přes které je během experimentu převáděna veškerá čištěná odpadní voda.

Pravé kořenové pole bylo k testování vybráno na základě vlastního pozorování a doporučení provozovatele. V prítokové části kořenového pole a pak dále až do cca poloviny kořenového pole byla na povrchu velká vrstva usazeného materiálu (až $20 \mathrm{~cm}$ stařiny mokřadní vegetace, usazeného kalu), docházelo k zaplavování přední části kořenového pole a rovněž účinnost čištění byla nižší, než jaké dosahovalo levé kořenové pole, a to i přes to, že byl průtok oběma poli velice podobný. Přes levé kořenové pole protékala v průběhu vlastního experimentu veškerá čištěná odpadní voda, ale i pres tuto skutečnost nedošlo k významnému poklesu účinnosti čištění, resp. k významnému zvýšení koncentrací sledovaných látek na odtoku z něj (tabulka 1). 
Je třeba ř́ci, že umělé mokřady jsou primárně určeny k odstraňování organického znečištění, nejsou určeny k odstraňování dusíku a fosforu. Účinnost čištění levého kořenového pole byla ve všech fázích experimentu zejména pro parametr nerozpuštěné látky velmi vysoká, odtokové koncentrace nerozpuštěných látek byly většinou velmi nízké, a to i v období, kdy levé kořenové pole čistilo veškerou přitékající odpadní vodu. Pouze v jednom prípadě byla u levého kořenového pole zjištěna odtoková koncentrace nerozpuštěných látek 43 mg/l, naopak v 16 prípadech byla naměřena koncentrace $<2 \mathrm{mg} / \mathrm{l}$. Velice zajímavé jsou i průměrné účinnosti čištění celkového dusíku v levém kořenovém poli, které se pohybovaly od 48,07 \% do $82,74 \%$. U pravého kořenového pole byly průměrné účinnosti čištění pro celkový dusík podstatně nižší, pohybovaly se od 19,71 \% do 46,91 \%, aplikace preparátu neměla na účinnost čištění celkového dusíku pozitivní vliv, stejně tak tomu bylo u celkového fosforu, kde jsou navíc účinnosti čištění velice rozkolísané.

Během testování v roce 2013 došlo k výraznému nárůstu koncentrací sledovaných látek na přítoku, nejméně u $\mathrm{CHSK}_{c r}$ - v průměru o cca $66 \%$ a nejvíce u $\mathrm{P}_{c}$ v průměru o cca $134 \%$. Podrobněji je kolísání koncentrací vybraných parametrů $\checkmark$ různých fázích experimentu patrné z grafů na obr. 4, 5 a 6.

K vyhodnocení experimentu byly odebírány dvouhodinové směsné vzorky, v období pred testováním 2013 bylo odebráno 8 vzorků, během testování 20136 vzorků, po testování 20136 vzorků, před testováním 20144 vzorky, během testování 20149 vzorků a po testování 20147 vzorků. Čistírna byla navštěvována $\checkmark$ dopoledních i odpoledních hodinách, aby bylo alespoň cástečně podchyceno kolísání průtoku a znečištění během dne.

Aby bylo možné vyhodnotit množství kolmatačního materiálu, byly odebírány vzorky kameniva. K odběru byl použit vrták, který se běžně používá k odběru vzorků zemin. Odebraný vzorek, který obsahoval kamenivo, stařinu rákosu a vlastní kolmatační materiál, byl několikrát důkladně propláchnut destilovanou vodou, aby došlo k oddělení jednotlivých částí. Ve vzorku kolmatačního materiálu byly stanoveny nerozpuštěné látky sušené a žíhané. Dále bylo zváženo množství čistého suchého kameniva a suché stařiny. Výsledky stanovení nerozpuštěných látek sušených a žíhaných byly přepočíány na odebraný kg kameniva. Výsledky shrnuje tabulka 2. Je z nich velice dobře patrné, že

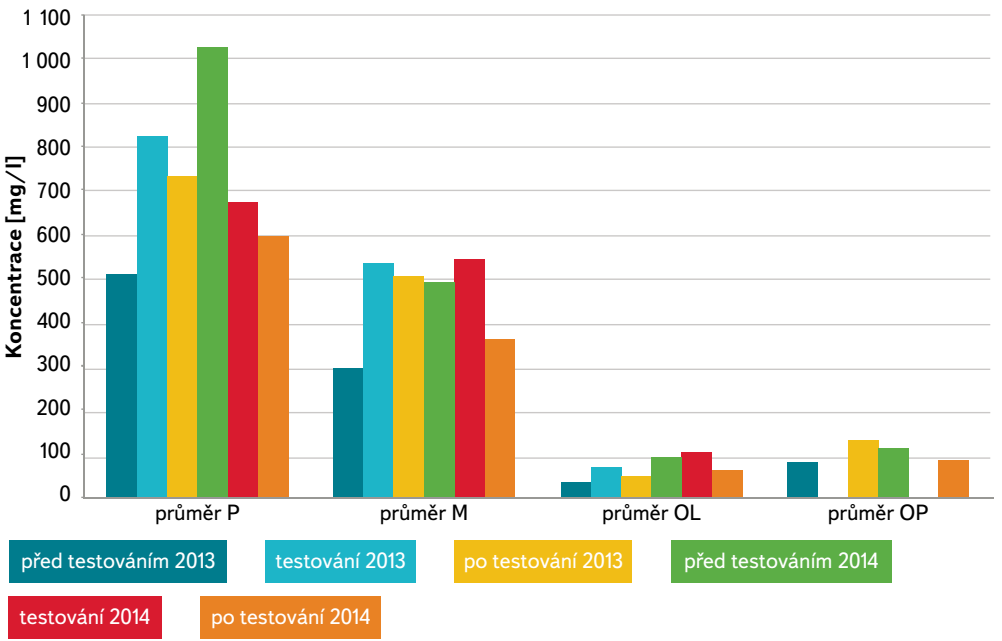

Obr. 4. Průměrné koncentrace $\mathrm{CHSK}_{\mathrm{cr}}$ na prítoku, za mechanickým předčištěním a na odtoku z levého a pravého kořenového pole v různých fázích experimentu

Fig. 4. Mean COD concentrations on the inflow, after mechanical pretreatment and on the outflow from the left and right parts of the constructed wetland during the different periods of experiment

jsou nerozpuštěné látky prítomné ve vysoké míře nejen v př́tokové zóně, ale i ve středu kořenového pole, a dokonce v odtokové zóně, to ukazuje na pokročilé zanesení filtrační náplně. Dále je z tabulky 2 patrné, že jsou zejména výsledky nerozpuštěných látek sušených značně rozkolísané. Na jejich základě rozhodně nelze tvrdit, že množství kolmatačního materiálu po aplikaci preparátu kleslo. Patrný je pouze rozdíl ve zjištěném množství stařiny na odklizené a neodklizené části kořenového pole. Príčinou rozkolísanosti výsledků může být nevhodně zvolený způsob odběru vzorku kameniva, protože v prípadě kořenových čistíren se jedná o prostředí trvale zatopené odpadní vodou.

Tabulka 1. Prưměrná účinnost čištěni a prưměrné koncentrace znečištěni na odtoku z levého (OL) a pravého (OP) kořenového pole v rưzných fázích experimentu Table 1. Mean treatment efficiency and mean pollution concentrations on the outflow from the left (OL) and right (OP) parts of the constructed wetland

\begin{tabular}{|c|c|c|c|c|c|c|c|}
\hline $\begin{array}{l}\text { KČOV Bezděkov } \\
\text { pod Třemšínem }\end{array}$ & & $\begin{array}{l}\text { CHSK }_{\mathrm{Cr}} \\
{[\% / \mathrm{mg} / \mathrm{l}]}\end{array}$ & $\begin{array}{l}\text { BSK }_{5} \\
{[\% / \mathrm{mg} / \mathrm{l}]}\end{array}$ & $\begin{array}{l}\text { NL105 } \\
{[\% / \mathrm{mg} / \mathrm{l}]}\end{array}$ & $\begin{array}{l}\mathbf{N}_{\text {amon. }} \\
{[\% / \mathrm{mg} / \mathrm{l}]}\end{array}$ & $\begin{array}{l}\mathbf{N}_{\mathrm{c}} \\
{[\% / \mathrm{mg} / \mathrm{l}]}\end{array}$ & $\begin{array}{l}\mathbf{P}_{\mathrm{c}} \\
{[\% / \mathrm{mg} / \mathrm{l}]}\end{array}$ \\
\hline \multirow{2}{*}{ před testováním 2013} & OL & 94,24 / 29 & $97,24 / 6$ & 96,12 / 7,1 & 75,42 / 9,1 & $82,74 / 9,8$ & $79,56 / 1,4$ \\
\hline & OP & 84,82 / 75 & $88,98 / 23$ & $96,79 / 5,9$ & $4,22 / 35$ & 31,79 / 39 & $12,94 / 5,8$ \\
\hline během testování 2013 & OL & 92,30 / 63 & $93,60 / 22$ & $99,23 / 2,9$ & $68,41 / 24$ & 77,98 / 25 & $63,84 / 5,6$ \\
\hline \multirow{2}{*}{ po testování 2013} & OL & 94,19 / 43 & $96,47 / 10$ & $98,68 / 3,3$ & $62,63 / 23$ & 74,42 / 26 & $72,44 / 3,5$ \\
\hline & OP & $83,04 / 124$ & 90,97 / 26 & 96,32 / 9,3 & $23,68 / 46$ & 44,32 / 57 & $8,19 / 12$ \\
\hline \multirow{2}{*}{ před testováním 2014} & OL & 91,45 / 87 & $92,93 / 24$ & $96,63 / 8,3$ & $51,80 / 43$ & $61,79 / 52$ & $56,96 / 6,4$ \\
\hline & OP & 89,05 / 112 & $96,29 / 12$ & $88,08 / 29$ & $32,17 / 60$ & $46,91 / 73$ & $71,45 / 4,3$ \\
\hline během testování 2014 & OL & $85,30 / 98$ & $90,26 / 23$ & $96,04 / 9,7$ & $46,89 / 40$ & $53,68 / 49$ & $51,86 / 7,3$ \\
\hline \multirow{2}{*}{ po testování 2014} & OL & $90,66 / 55$ & $94,56 / 12$ & 98,19 / 4,1 & 38,55 / 34 & $48,07 / 38$ & $53,12 / 4,9$ \\
\hline & OP & $85,87 / 84$ & $92,85 / 15$ & $96,33 / 8,3$ & $9,11 / 50$ & $19,71 / 58$ & $39,92 / 6,3$ \\
\hline
\end{tabular}




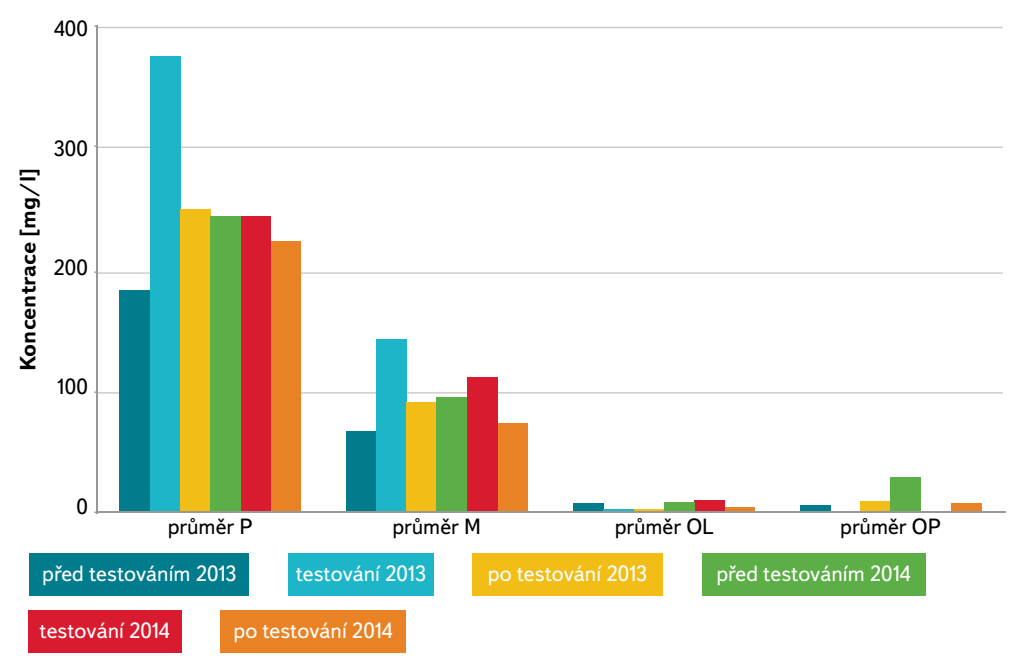

Obr. 5. Prưměrné koncentrace NL na prítoku, za mechanickým předčištěním a na odtoku z levého a pravého kořenového pole v různých fázích experimentu

Fig. 5. Mean SS (suspended solids) concentrations on the inflow, after mechanical pretreatment and on the outflow from the left and right parts of the constructed wetland during the different periods of experiment

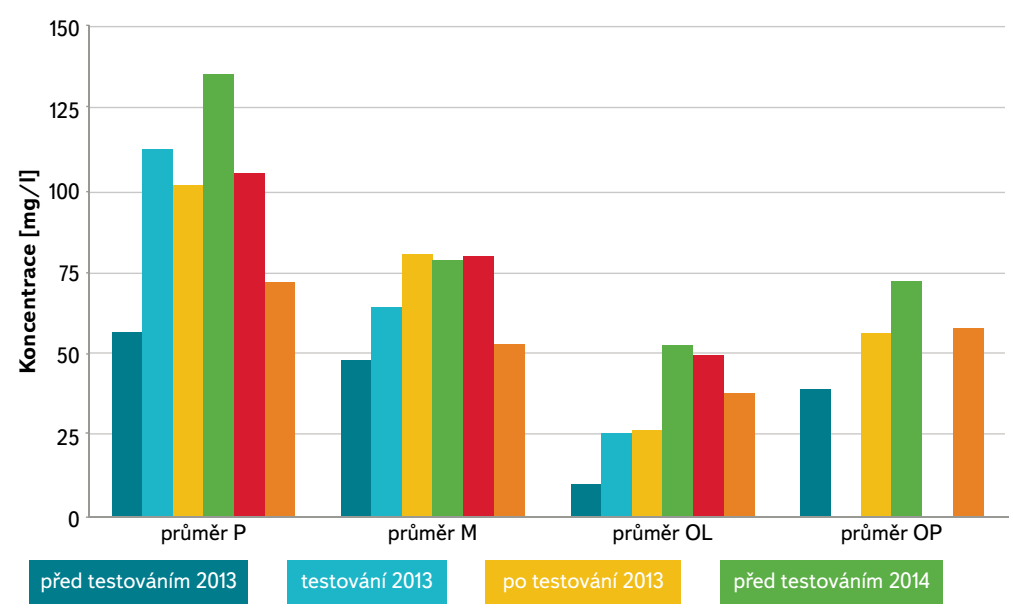

\section{testování 2014 po testováni 2014}

Obr. 6. Průměrné koncentrace celkového dusíku na prítoku, za mechanickým předčištěním a na odtoku z levého a pravého kořenového pole v rưzných fázích experimentu

Fig. 6. Mean total nitrogen concentrations on the inflow, after mechanical pretreatment and on the outflow from the left and right parts of the constructed wetland during the different periods of experiment

Tabulka 2. Výsledky analýzy odebraného kameniva - množstvíkameniva, množstvístařiny, množstvínerozpuštěných látek sušených a žihaných na kg čistého suchého kameniva Table 2. The results of the sampled gravel analysis - amount of dry pure gravel, amount of old vegetation, amount of dry and ignited suspended solids per kg of dry pure gravel

\begin{tabular}{|c|c|c|c|c|c|c|}
\hline $\begin{array}{l}\text { Odběrový profil pravého } \\
\text { kořenového pole }\end{array}$ & Datum odběru & $\begin{array}{l}\text { Kamenivo } \\
{[\mathrm{g}]}\end{array}$ & $\begin{array}{l}\text { Zjištěná stařina } \\
{[\mathrm{g}]}\end{array}$ & $\begin{array}{l}\text { NL105 } \\
{[\mathrm{g} / \mathrm{kg}]}\end{array}$ & $\begin{array}{l}\text { NL550 } \\
{[\mathrm{g} / \mathrm{kg}]}\end{array}$ & $\begin{array}{l}\text { Organický podíl } \\
{[\%]}\end{array}$ \\
\hline přítoková zóna & 15. 5. 2013 & 2413,2 & 38,1 & 31,8 & 24,1 & 24,1 \\
\hline střed pole & 15. 5. 2013 & 490,9 & 10,2 & 25,0 & 20,4 & 18,4 \\
\hline odtoková zóna & 15. 5. 2013 & 590,4 & 5,6 & 28,2 & 24,0 & 14,8 \\
\hline přítoková zóna & 24. 7. 2013 & 2065,8 & 5,8 & 29,7 & 21,5 & 27,7 \\
\hline přítoková zóna & 14. 8. 2013 & 1699,9 & 7,0 & 28,1 & 22,6 & 19,4 \\
\hline přítoková zóna & 4. 12. 2013 & 1985,2 & 18,4 & 38,7 & 24,0 & 38,7 \\
\hline odklizená přítoková zóna & 13. 5. 2014 & 1784,8 & 10,9 & 19,9 & 18,7 & 6,3 \\
\hline neodklizená přítoková zóna & 13. 5. 2014 & 1907,3 & 19,7 & 24,7 & 18,4 & 25,2 \\
\hline odklizená přítoková zóna & 27. 5. 2014 & 1495,3 & 6,1 & 26,1 & 19,2 & 26,5 \\
\hline neodklizená přítoková zóna & 27. 5. 2014 & 1838,2 & 34,3 & 25,5 & 23,5 & 7,8 \\
\hline odklizená přítoková zóna & 19. 8. 2014 & 992,3 & 1,7 & 30,6 & 26,6 & 13,0 \\
\hline neodklizená přítoková zóna & 19. 8. 2014 & 1573,1 & 18,7 & 40,4 & 27,4 & 32,1 \\
\hline odklizená přítoková zóna & 16. 9.2014 & 923,6 & 2,6 & 36,5 & 27,2 & 25,7 \\
\hline neodklizená přítoková zóna & 16. 9.2014 & 1157,0 & 8,0 & 29,4 & 25,8 & 12,2 \\
\hline
\end{tabular}




\section{ZÁVĚR}

Nejdůležitějším krokem je předcházení vzniku a rozvoje kolmatace volbou vhodného a dostatečně dimenzovaného mechanického predčištění, jeho správným provozováním spojeným s dostatečně častým vyvážením kalového prostoru usazovací nádrže. Dủležitá je i vhodná volba filtrační náplně. Tyto faktory mohou významnou měrou zvýšit dobu životnosti umělého mokřadu.

S ohledem na skutečnost, že je kolmatace zcela obvyklým jevem, je většinou třeba dřive či později přistoupit k opatřením vedoucím ke zvýšení propustnosti a účinnosti čištění ucpané filtrační náplně.

Provedený experiment nepotvrdil, že aplikace bakteriálně-enzymatického preparátu do zakolmatované filtrační náplně kořenové čistírny $v$ Bezděkově pod Třemšínem měla vliv na snížení množství nerozpuštěných látek přítomných ve filtrační náplni. Výsledky experimentu dále ukazují, že v době, kdy byla veškerá odpadní voda čištěna v levém kořenovém poli, nedošlo k významnému snížení účinnosti čištění tohoto kořenového pole, resp. nedošlo k významnému nárůstu koncentrací na odtoku z něj. U pravého kořenového pole došlo zejména po aplikaci preparátu v roce 2014 ke zvýšení účinnosti čištění, resp. k významnému snížení odtokové koncentrace nerozpuštěných látek.

Provedený experiment jednoznačně nepotvrdil, že je aplikace biologicko-enzymatického preparátu vhodnou cestou ke snížení rozsahu kolmatace filtrační náplně a ke zvýšení účinnosti čištění.

Více informací nejen o kolmataci naleznete v publikaci Optimalizace provozu a zvýšení účinnosti čištění odpadních vod z malých obcí pomocí extenzivních technologií autorského kolektivu Mlejnská, Rozkošný, Baudišová, kterou vydal v roce 2015 Výzkumný ústav vodohospodárský T. G. Masaryka, v. v. i.

\section{Poděkování}

Tento príspěvek vznikl v rámci implementace projektu TA02020128 - Výzkum možností optimalizace provozu a zvýšení účinnosti čištěni odpadních vod z malých obcí pomoci extenzivních technologii, který byl řešen v letech 2012-2015 s finanční podporou TA ČR v rámci programu Alfa.

\section{Literatura}

[1] REDDI, L.N., XIAO, M., HAJRA, M.G., and LEE, I.M. Permeability reduction of soil filters due to physical clogging. Journal of Geotechnical and Geoenvironmental Engineering, 2000, vol. 126, No. 3, p. 236-247.

[2] WINTER, K.J. and GOETZ, D. The impact of sewage composition on the soil clogging phenomena of vertical flow constructed wetlands. Water Science and Technology, 2003, vol. 48, No. 5, p. 9-14.

[3] SCHWARZ, M., FUCHS, S., and HAHN, H.H. Nucleic acids: indicators for dynamic processes of clogging in soil filter systems. Water Science and Technology, 2006, vol. 54, No. 11-12, p. 183-189.

[4] SIRIWARDENE, N.R., DELETIC, A., and FLETCHER, T.D. Clogging of stormwater gravel infiltration systems and filters: Insights from a laboratory study. Water Research, 2007, vol. 41, No. 7, p. 1433-1440.

[5] PEDESCOLL, A., UGGETTI, E., LLORENS, E., GRANÉS, F., GARCÍA, D., and GARCíA, J. Practical method based on saturated hydraulic conductivity used to assess clogging in subsurface flow constructed wetlands. Ecological Engineering, 2009, vol. 35, No. 8, p. 1216-1224.

[6] PEDESCOLL, A., CORZO, A., ÁlVAREZ, E., GARCíA, J., and PUIGAGUT, J. The effect of primary treatment and flow regime on clogging development in horizontal subsurface flow constructed wetlands: An experimental evaluation. Water Research, 2011, vol. 45, No. 12, p. 3579-3589.

[7] KAYSER, K. and KUNST, S. Processes in vertical-flow reed beds: nitrification, oxygen transfer and soil clogging. Water Science and Technology, 2005, vol. 51, No. 9, p. 177-184.

[8] HUA, G.F., ZHU, W., ZHAO, L.F., and HUANG, J.Y. Clogging pattern in vertical-flow constructed wetlands: Insight from a laboratory study. Journal of Hazardous Materials, 2010, vol. 180, No. 1-3, p. 668-674.

[9] LI, H.Z., WANG, S., YE, J.F., XU, Z.X., and JIN, W. A practical method for the restoration of clogged rural vertical subsurface flow constructed wetlands for domestic wastewater treatment using earthworm. Water Science and Technology, 2011, vol. 63, No. 2, p. 283-290.

[10] TANNER, C.C. and SUKIAS, J.P. Accumulation of organic solids in gravel-bed constructed wetlands. Water Science and Technology, 1995, vol. 32, No. 3, p. 229-239.
[11] HYÁNKOVÁ, E. Příčiny a možnosti minimalizace kolmatačních jevůve filtračních náplních kořenových čistíren. In: Sborník prednášek ze semináre Prírodní zpưsoby čištěni vod V. Brno: CERM, 2007, s. 26-31.

[12] ROUSSEAU, D.P.L., VANROLLEGHEM, P.A., and DE PAUW, N. Constructed wetlands in Flanders: a performance analysis. Ecological Engineering, 2004, vol. 23, No. 3, p. 151-163.

[13] TURON, C., COMAS, J., and POCH, M. Constructed wetland clogging: A proposal for the integration and reuse of existing knowledge. Ecological Engineering, 2009, vol. 35, No. 12, p. 1710-1718.

[14] KNOWLES, P., DOTRO, G., NIVALA, J., and GARCÍA, J. Clogging in subsurface-flow treatment wetlands: Occurrence and contributing factors. Ecological Engineering, 2011, vol. 37, No. 2, p. 99-112.

[15] PLATZER, CH. and MAUCH, K. Soil clogging in vertical flow reed beds - Mechanisms, parameters, consequences and solutions? Water Science and Technology, 1997, vol. 35, No. 5, p. 175-181.

[16] HUA, G., ZHU, W., ZHAO, L., and ZHANG, Y. Applying solubilisation treatment to reverse clogging in laboratory-scale vertical flow constructed wetlands. Water Science and Technology, 2010, vol. 61, No. 6, p. 1479-1487.

[17] TUSZYŃSKA, A. and OBARSKA-PEMPKOWIAK, H. Speciation of organic matter in vertical flow constructed wetlands. Polish Journal of Environmental Studies, 2009, vol. 18, No. 4, p. 735-740.

[18] MLEJNSKÁ, E., ROZKOŠNÝ, M. a BAUDIŠOVÁ, D. Optimalizace provozu a zvýšeni účinnosti čištěni odpadních vod z malých obcípomociextenzivních technologií. Praha: Výzkumný ústav vodohospodářský T. G. Masaryka, v. v. i., 2015, 160 s.

[19] MALÁ, E., ŠÁLEK, J. a KRIŠKA-DUNAJSKÝ, M. Poznatky z výzkumu kolmace filtračního prostředí zemnich filtrů. In: Zborník z konferencie Odpadové vody 2004. Nitra: AČE SR, 2004, s. 329-335. ISBN 80-89088-33-3.

[20] HYÁNKOVÁ, E. a ŠÁLEK, J. Poznatky z výzkumu kolmace filtračního prostředí vegetačních kořenových čistíren s vertikálním prouděním. 3. vodohospodářská konference 2003, Brno: FAST VUT, 2003, s. 441-447.

[21] ZHAO, L., ZHU, W., and TONG, W. Clogging processes caused by biofilm growth and organic particle accumulation in lab-scale vertical flow constructed wetlands. Journal of Environmental Sciences, 2009, vol. 21, No. 6, p. 750-757.

[22] NIVALA, J., KNOWLES, P., DOTRO, G., GARCíA, J., and WALLACE, S. Clogging in subsurface-flow treatment wetlands: Measurement, modelling a management. Water Research, 2012, vol. 46, No. 6, p. $1625-1640$.

[23] KRŠŇÁK, M. Projektování KČOV druhé generace. In: Kriška, M., Šálek, J., Plotěný, K. Př́rodní zpưsoby čištěnívod VI. Brno: Akademické nakladatelství CERM, 2009, 134 s.

[24] NIVALA, J. and ROUSSEAU, D.P.L. Reversing clogging in subsurface-flow constructed wetlands by hydrogen peroxide treatment: two case studies. Water Science and Technology, 2009, vol. 59, No. 10, p. 2037-2046

[25] WANNER, F. a MLEJNSKÁ, E. Uvolnění zakolmatovaného lože zemního filtru in-situ aplikací enzymů. Vodníhospodárství, 2010, vyd. 52, č. 12, s. 15-18.

\section{Autor}

\section{Ing. Eva Mlejnská}

凶eva.mlejnska@vuv.cz

Výzkumný ústav vodohospodářský T. G. Masaryka, v. v. i.

Přispěvek prošel lektorským řízením. 


\section{CONSTRUCTED WETLANDS CLOGGING}

\section{MLEJNSKA, $E$.}

TGM Water Research Institute, p. r. i.

Keywords: constructed wetland - clogging hydraulic load - organics - treatment efficiency

Clogging is a quite natural process, but it is an undesirable phenomenon in artificial wetlands used for treatment and tertiary treatment of wastewaters. Due to this, it is necessary, during proposal preparation and operation of artificial wetlands, to keepthe principlesthatmightsignificantly restricttheriseand progress of clogging. Sufficient adjustment and right operation of mechanical pre-treatment, suitable selection of filter fill of constructed wetland, organic and hydraulic loading, conditions of operation and another ones, belong to the principles mentioned. In the case, clogging comes in and its extent influences efficiency of treatment or amount of treated wastewater it is necessary to exchange or regenerate filter fill of constructed wetland.

The paper summarizes experiences with in-situ application of bacteria-enzymatic agent in the clogging constructed wetland. 